\title{
Influence of a transplantable insulinoma on the pancreatic status of insulin and pancreatic polypeptide in the rat
}

\author{
M.M.T.O'Hare', C.Shaw ${ }^{1}$, S. K. Swanston-Flatt ${ }^{2}$, M. Marcelli1 ${ }^{1}$, K. D. Buchanan ${ }^{1}$ and P. R. Flatt ${ }^{2}$ \\ 'Department of Medicine, The Queen's University of Belfast, Northern Ireland, and 'Division of Nutrition and Food Science, University of \\ Surrey, Guildford, Surrey, UK
}

\begin{abstract}
Summary. The effect of endogenous hyperinsulinaemia, produced by syngeneic transplantation of rat insulinoma at an extrapancreatic site, on pancreatic insulin and pancreatic polypeptide has been examined by radioimmunoassay and immunohistochemistry. Twenty days after subcutaneous transplantation, tumour-bearing rats exhibited marked hyperinsulinaemia and hypoglycaemia, with plasma pancreatic polypeptide concentrations similar to controls. Immunoreactive insulin levels in the head and tail of pancreas of tumourbearing rats were reduced by $90-95 \%$ compared with control animals. Immunoreactive pancreatic polypeptide levels in the head of the pancreas were reduced by $70 \%$, but the relatively
\end{abstract}

low levels of peptide in the pancreatic tail were similar in tumour-bearing and control rats. Insulin and pancreatic polypeptide cells were weakly immunofluorescent in tumour-bearing rat pancreas. In conclusion, the presence of an insulinoma at an extrapancreatic site resulted in a severe depletion of endogenous insulin and pancreatic polypeptide, suggesting that there is a functional relationship between the beta and pancreatic polypeptide cell.

Key words: Transplantable insulinoma, islet cell tumour, insulin, pancreatic polypeptide, radioimmunoassay, immunohistochemistry.
Previous studies, using the transplantable $\mathrm{X}$-ray induced rat insulinoma described by Chick and colleagues, have demonstrated that these tumours contain large quantities of immunoreactive insulin (IRI) and are predominantly composed of well-granulated $\beta$-like cells [1]. The release of insulin by glucose [2] and other putative secretagogues [3] suggests that this model is a useful source of large quantities of functional $\beta$-cells. The model is also suitable for studying the effects of endogenous hyperinsulinaemia in the rat and since the circulating insulin is of rat origin this eliminates the problem of species variation.

Levels of IRI, glucagon and somatostatin in these tumours have been described previously [2]. However, the tumour content of immunoreactive pancreatic polypeptide (PP) and the influence of hyperinsulinaemia on the pancreatic status of PP have not been possible to evaluate due to the lack of a specific antiserum for rat PP. Using an antiserum raised to the highly-conserved C-terminal hexapeptide sequence $[4,5]$, quantitation of rat $\mathrm{PP}$ is now possible.

\section{Materials and methods}

\section{Animals}

Small minced fragments of a serially transplantable radiation-induced insulinoma (approximately $0.1 \mathrm{~g}$ ) [1] from a single donor rat were implanted subcutaneously into the subscapular region of 12-13-week-old male inbred NEDH rats (New England Deaconess Hospital, Boston, Mass., USA). The colony of insulinoma-bearing rats was established at Guildford in 1980 from breeding pairs kindly provided by Professors W.L. Chick (Boston, Mass., USA) and C. N. Hales (Cambridge, UK). After 20 days, blood was obtained at $10.00 \mathrm{~h}$ from fed rats by cardiac puncture and the tumour and pancreas were excised from each rat for radioimmunoassay and immunohistochemistry. The stomachs of both groups of rats contained food at the time of death. At this time, the animals exhibited symptoms of hypoglycaemia with plasma glucose concentrations measured by the glucose oxidase procedure [6] in the range $0.5-3.2 \mathrm{mmol} / \mathrm{l}$. Untreated rats of similar age and sex were used as controls. The animals were housed in an air conditioned room at $22 \pm 2{ }^{\circ} \mathrm{C}$ with a lighting schedule of $12 \mathrm{~h}$ light (07.00-19.00 h) and $12 \mathrm{~h}$ dark. A standard pellet diet (Spratts laboratory diet No.1, Lillico, Reigate, Surrey, UK) and tap water were supplied ad libitum.

\section{Extraction of hormones}

Tumour tissue and head and tail regions of pancreas from tumourbearing $(n=6)$ and control rats $(n=6)$ were snap frozen in liquid nitrogen and stored at $-20^{\circ} \mathrm{C}$ prior to hormone extraction. Tissue was extracted in acidified ethanol using a modification of the Kenny technique [7]. After drying under air and reconstitution in phosphate buffer $(0.04 \mathrm{~mol} / 1, \mathrm{pH} 7.4)$, the insulin and PP content were determined by specific radioimmunoassays (see below), as were non-fasting plasma levels. Blood samples were processed as previously described [8].

\section{Insulin radioimmunoassay}

The antiserum used in the insulin radioimmunoassay was GP 25, raised in guinea-pigs against porcine insulin and used at a final dilution of 1:360000. Rat insulin (Novo Industri, Copenhagen, Denmark) was used as standard. Porcine insulin was labelled with ${ }^{125} \mathrm{I}$ using chloramine $\mathrm{T}$ and purified on microfine silica. The assay can distinguish $0.5 \mathrm{mU} / 1$ of insulin from zero with $95 \%$ confidence. 


\section{$P P$ radioimmunoassay}

The PP radioimmunoassay utilised an antiserum (PP221) raised against the synthetic C-terminal hexapeptide of PP (UCB Bioproducts, Brussels, Belgium) and used at a final dilution of $1: 72000$. This antiserum did not cross-react with porcine peptide YY or neuropeptide Y [9]. Bovine PP (Dr. R. E. Chance, Eli Lilly, Indianapolis, Indiana, USA) was used as standard and tracer in the assay. The assay system and purification of tracer have been described previously [8].

\section{Immunohistochemistry}

Head and tail regions of pancreas from both control $(n=6)$ and tumour-bearing rats $(n=6)$ were fixed in Bouin's fluid for $24 \mathrm{~h}$. Excess fixative was removed by several changes of $70 \%$ ethanol and tissues were subsequently processed as per routine paraffin techniques. Insulinoma tissue $(n=6)$ was similarly processed.

Serial sections $(5 \mu)$ of each specimen were immunostained for insulin and PP using indirect immunofluorescence. Primary insulin antisera (GP 11, 1:500) and PP antiserum (PP 221, 1:80) were incubated with sections for $2 \mathrm{~h}$ at $25^{\circ} \mathrm{C}$ and after washing in phosphate-buffered saline, the secondary antibody which was either fluorescein-conjugated swine anti-rabbit immunoglobulin or swine anti-guinea pig immunoglobulin (Dako Immunoglobins, Glostrup, Denmark) was incubated at 1:20 dilution with sections for a further $20 \mathrm{~min}$. After a final wash and mounting, sections were viewed under a fluorescence microscope (Olympus BH, Olympus Opticals, Tokyo, Japan). Standard controls were included in each staining batch.

Table 1. Insulin and PP content of control and tumour-bearing rat pancreas

\begin{tabular}{llllll}
\hline Animal & \multicolumn{3}{l}{ Insulin $(\mathrm{U} / \mathrm{g})$} & $\mathrm{PP}(\mu \mathrm{g} / \mathrm{g})$ & \\
\hline Control & Head & $3.9 \pm 0.7$ & $(2.9-5.8)$ & $4.2 \pm 0.8$ & $(2.9-8.3)$ \\
rat & Tail & $6.7 \pm 1.2$ & $(3.9-9.5)$ & $0.19 \pm 0.02$ & $(0.14-0.25)$ \\
Insulinoma- & Head & $0.4 \pm 0.2^{\mathrm{a}}$ & $(0.04-1.6)$ & $1.3 \pm 0.2^{\mathrm{b}}$ & $(0.8-1.9)$ \\
bearing rat & Tail & $0.2 \pm 0.03^{\mathrm{a}}(0.04-0.24)$ & $0.18 \pm 0.03$ & $(0.14-0.28)$ \\
\hline
\end{tabular}

Values expressed as mean \pm SEM with ranges in parentheses for groups of six rats. ${ }^{a} p<0.0005 ;{ }^{b} p<0.01$ compared with control rats

\section{Statistical analysis}

Results are expressed as mean \pm SEM. The Student's t-test (twotailed) was applied to paired and unpaired values with the level of significance of $p<0.05$.

\section{Results}

\section{Radioimmunoassay}

IRI content: compared with control levels in the head and tail of pancreas, insulinoma tissue contained significantly greater quantities of IRI $(36.6 \pm 5.7 \mathrm{U} / \mathrm{g} ; p<$ 0.0025 ). However, pancreatic tissue from tumour-bearing rats contained significantly lower levels in the head and tail compared with controls ( $p<0.0005$; Table 1 ).

Immunoreactive PP content: Insulinoma tissues contained detectable quantities of immunoreactive PP $(8.9 \pm 1.3 \mathrm{ng} / \mathrm{g})$. However, the levels detected were low compared with pancreatic levels in control animals (Table 1). A significant reduction in the immunoreactive PP content of the head region of pancreas in tumourbearing rats was observed when these were compared with levels in control animals $(p<0.01$; Table 1$)$. The levels of immunoreactive PP detected in the tail region were not significantly different in these groups of animals.

Circulating concentrations: non-fasting circulating IRI concentrations were grossly elevated $(5200 \pm 990 \mathrm{mU} / \mathrm{l}$; $p<0.001)$ and glucose concentrations decreased $(2.0 \pm$ $0.4 \mathrm{mmol} / 1 ; p<0.001$ ) in tumour-bearing rats compared with controls $(30.8 \pm 6.9 \mathrm{mU} / 1$ and $6.4 \pm 0.5$
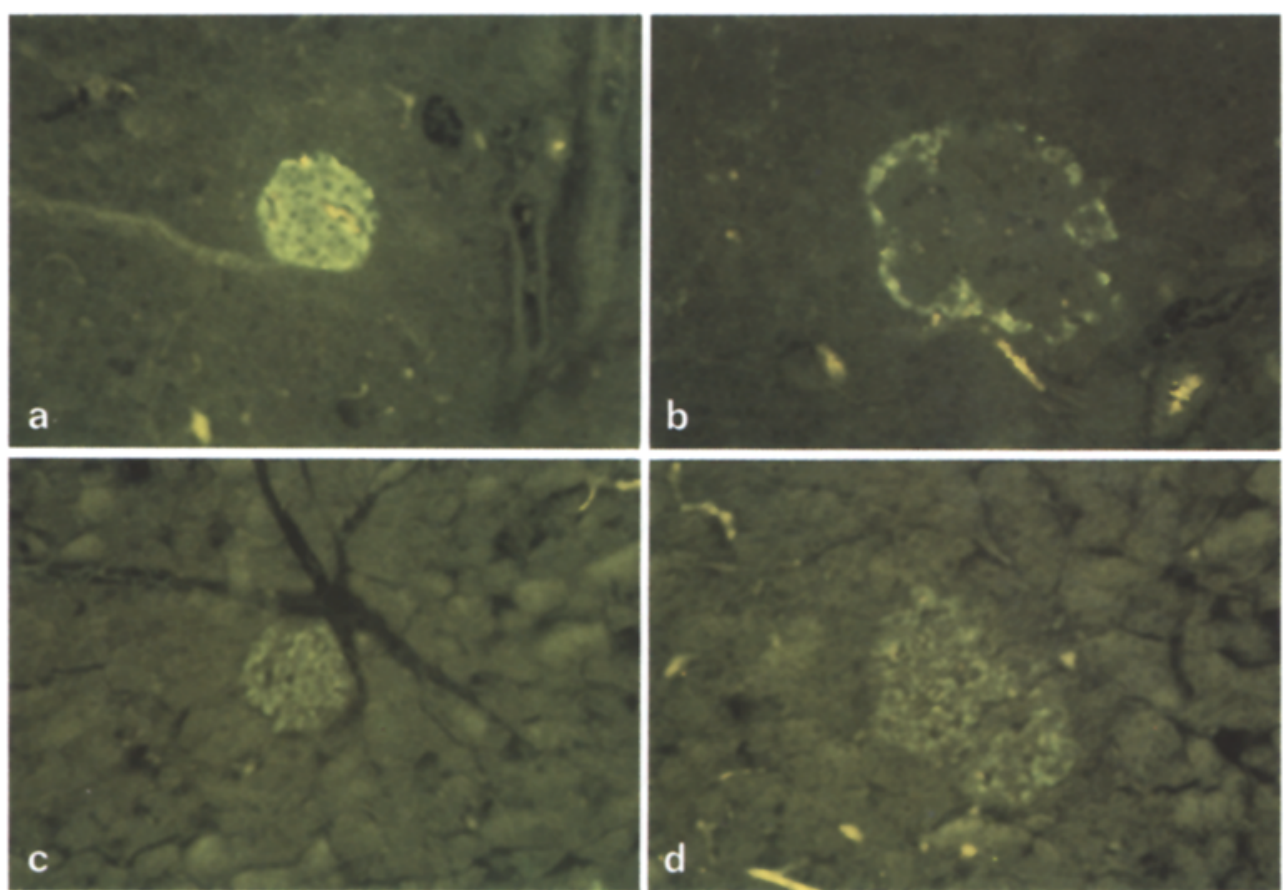

Fig. 1a-d. Immunofluorescent staining in sections of control rat pancreas with anti-insulin serum (a) and anti-PP serum (b). Examples of the pattern of staining in sections of pancreatic tissue from tumourbearing rats with anti-insulin serum $(c)$ and anti-PP serum (d) are also shown. $(\times 400)$ 
$\mathrm{mmol} / \mathrm{l}$, respectively). However, similar immunoreactive PP levels were detected in the two groups (tumourbearing, $198 \pm 62 \mathrm{ng} / \mathrm{l}$, range $60-480$; controls, $153 \pm$ $51 \mathrm{ng} / \mathrm{l}$, range $35-350$ ).

\section{Immunohistochemistry}

Sections of insulinoma displayed no PP immunoreactivity and a weak reaction with insulin antiserum (data not shown). This staining could not be intensified by either increasing primary antiserum concentration or prolonging staining time. Sections of control pancreas displayed the normal pattern of both insulin and PP immunoreactivity (Fig. $1 \mathrm{a}$ and $\mathrm{b}$ ), whereas sections of pancreas from tumour-bearing rats did not. Both insulin- and PP-immunoreactive cells were extremely difficult to locate due to their exceptionally low-intensity staining (Fig. 1 $\mathrm{c}$ and $\mathrm{d}$ ).

\section{Discussion}

The transplantable insulinoma used in this study is a suitable model for studying the effects of endogenous hyperinsulinaemia in the rat. An advantage of this model is that it eliminates the problem of intra species primary sequence variations in mammalian insulins, since the effect of elevated circulating rat insulin is studied. Furthermore, the tumours are located at an extra-pancreatic site, thus eliminating any local or paracrine effect of insulin release from a pancreatic insulinoma.

Elevated concentrations of IRI and hypoglycaemia were detected in all tumour-bearing rats, indicating that the tumours were functional. However, it was not possible to obtain fasting plasma samples from these animals due to their deteriorating metabolic state and dependence on food to counter hypoglycaemia [10]. This is a requirement for the reliable evaluation of circulating PP concentrations, which rise dramatically in response to food $[11,12]$. Nevertheless, the failure to observe increased PP concentrations in the tumour-bearing rats clearly indicates that PP is not a reliable marker for the diagnosis of insulinomas $[8,13]$. Ideally, the radioimmunoassay for rat PP requires a rat PP standard as in the radioimmunoassay of rat insulin. However, the PP radioimmunoassay employed, enabled a more accurate estimation of the pancreatic content of $\mathrm{PP}$ than has been previously possible. This revealed a dramatic regional variation, the head region of pancreas containing significantly greater quantities of immunoreactive PP compared to tail. This confirms the immunohistochemical observation of Orci et al. [14] who demonstrated greater numbers of PP cells in islets located in the head region of pancreas than in islets located in the tail region.

The suppression of $\beta$-cell activity in tumour-bearing rats has been described previously [1] and similar observations have been noted in rats treated with large quantities of exogenous insulin $[15,16]$, suggesting that this phenomenon is directly related to circulating insulin concentrations. In the case of PP, the selective suppression of hormone levels in the head of the pancreas cannot be attributed to release of PP from the tumour since the tumours contained very low levels and the tumour-bearing rats had similar circulating PP concentrations to controls. These observations suggest that the suppression of PP is related to circulating insulin concentrations.

Parallel immunohistochemistry of tumour-bearing rat pancreas revealed a similar pattern of disturbance to that observed by radioimmunoassay. Both insulin and PP immunoreactive cells were difficult to locate due to their poor staining characteristics, indicating a considerable reduction in synthetic/storage mechanisms. The reduced staining intensity of $\beta$-cells can be attributed to functional inactivity since tumour resection results in hypoinsulinaemia and transient hyperglycaemia [17]. However, the basis for the observed changes in PP cells is far less clear. Thus the possibilities that depletion of PP stores are due to functional suppression or hypersecretion cannot be distinguished on the basis of plasma $\mathrm{PP}$ concentrations measured in fed rats at one point in time.

In insulin deficiency states, e.g. insulin-dependent and non-insulin dependent diabetes, immunoreactive PP is elevated [18]. This was initially thought to be due to PP-cell hyperplasia [19]. However, when circulating insulin concentrations are increased, e.g. with treatment a significant reduction in circulating PP concentrations is observed [20]. These results suggest that PP cell activity is regulated by changes in circulating insulin concentrations. Therefore, a functional relationship may exist between the $\beta$ - and PP-cells within the islet.

Acknowledgements. This work was supported in part by the Cancer Research Campaign (SP-1630) and the Ulster Cancer Foundation. We are grateful to Mrs. M. Barbour for secretarial assistance.

\section{References}

1. Chick WL, Warren S, Chute RN, Like AA, Lauris V, Kitchen KG (1977) A transplantable insulinoma in the rat. Proc Natl Acad Sci USA 74: 628-632

2. Masiello P, Wollheim CB, Janjic D, Gjinovci A, Blondel B, Praz GA, Renold AE (1982) Stimulation of insulin release by glucose in a transplantable rat islet cell tumour. Endocrinology III: 2091-2096

3. Sopwith AM, Hutton JC, Naber SP, Chick WL, Hales CN (1981) Insulin secretion by a transplantable rat islet cell tumour. Diabetologia 21: 224-229

4. Taylor IL, Vaillant CR (1983) Pancreatic polypeptide-like material in nerves and endocrine cells of the rat. Peptides $4: 245-253$

5. O'Hare MMT (1983) Pancreatic polypeptide in diabetes mellitus. In: Mngola EN (ed) Diabetes 1982. Excerpta Medica, Amsterdam, Oxford, Princeton, International Congress Series 600, pp 517-523

6. Stevens JF (1971) Determination of glucose by automatic analyser. Clin Chim Acta 32: 199-201 
7. Kenny AJ (1955) Extractable glucagon of the human pancreas. J Clin Endocrinol 15: 1089-1105

8. O'Hare MMT, Daly JG, Buchanan KD (1983) Radioimmunoassay for pancreatic polypeptide, and its age-related changes in concentration. Clin Chem 29: 1923-1927

9. O'Hare MMT, Chen M-H, Tatemoto K, Buchanan KD, Joffe SN, Murphy RF (1983) Lack of crossreactivity of peptide YY (PYY) and neuropeptide Y (NPY) with antibodies to pancreatic polypeptide (PP) in radioimmunoassay. Clin Chem 29: 1553-1554

10. Swanston-Flatt SK, Flatt PR, Tan K, Marks V (1982) A transplantable rat insulinoma induces hyperphagia and abolishes diurnal changes of food consumption, plasma glucose and plasma insulin concentrations. Proc Nutr Soc 41: 130 A

11. Taylor IL, Feldman M, Richardson CT, Walsh JH (1978) Gastric and cephalic stimulation of human pancreatic polypeptide release. Gastroenterology 75: 432-437

12. Adrian TE, Bloom SR, Besterman HS, Barnes AJ, Cooke TJC, Russell RCG, Faber RG (1977) Mechanism of pancreatic polypeptide release in man. Lancet 1: 161-163

13. Nelson RL, Service FJ, Ilstrup DM, Go VLW (1980) Are elevated pancreatic polypeptide levels in patients with insulinoma secondary to hypoglycaemia? Lancet 2:659-661

14. Orci L, Baetens D, Ravazzola M, Stefan Y, Malaisse-Lagae F (1976) Pancreatic polypeptide and glucagon: non-random distribution in pancreatic islets. Life Sci 19: 1811-1816

15. Latta JS, Harvey HT (1942) Changes in the islets of Langerhans of the albino rat induced by insulin administration. Anat $\operatorname{Rec} 82$ : 281-295

16. Logothetopoulos J, Kaneko M, Wrenshall GA, Best CH (1964)
Zinc, granulation and extractable insulin of islet cells following hyperglycaemia or prolonged treatment with insulin. In: Brolin SE, Hellman B, Knutson H (eds) The structure and metabolism of the pancreatic islets. Pergamon Press, Oxford, pp 333-347

17. Flatt PR, Tan K, Bailey CJ, Swanston-Flatt SK, Marks V, Webster JD (1982) Plasma glucose and insulin concentrations after implantation and surgical resection of a transplantable rat insulinoma. Biochem Soc Trans 10: 273-274

18. Floyd Jr JC, Fajans SS, Pek S, Chance RE (1977) A newly recognised pancreatic polypeptide; plasma levels in health and disease. Recent Prog Horm Res 33: 519-570

19. Gepts W, De Mey J, Marichal-Pipeleers M (1977) Hyperplasia of 'pancreatic polypeptide'-cells in the pancreas of juvenile diabetes. Diabetologia 13: 27-34

20. Berger D, Floyd JC, Pek SB (1981) The effect of treatment of Type 2 (insulin independent) diabetes mellitus on plasma concentrations of pancreatic polypeptide and glucagon. Diabetologia 21: $120-125$

Received: 17 May 1984

and in revised form: 3 December 1984

Dr. M.M.T.O'Hare

Department of Medicine

The Queen's University of Belfast

Institute of Clinical Science

Grosvenor Road

Belfast BT12 6BJ

Northern Ireland 